\title{
Vagococcus acidifermentans sp. nov., isolated from an acidogenic fermentation bioreactor
}

\author{
Liang Wang, ${ }^{1}$ Ying-Shun Cui, ${ }^{1}$ Chang Seob Kwon, ${ }^{2}$ Sung-Taik Lee, ${ }^{1}$ \\ Jung-Sook Lee ${ }^{3}$ and Wan-Taek Im $^{2}$ \\ ${ }^{1}$ Department of Biological Sciences, Korea Advanced Institute of Science and Technology, 373-1, \\ Guseong-dong, Yuseong-gu, Daejeon 305-701, Republic of Korea \\ ${ }^{2}$ Department of Oriental Medicinal Material and Processing College of Life Science, Kyung Hee \\ University, Seocheon-dong, Giheung-gu, Yongin-si, Gyeonggi-do 446-701, Republic of Korea \\ ${ }^{3}$ Korean Collection for Type Cultures (KCTC), Korea Research Institute of Bioscience and \\ Biotechnology, 52 Oeundong, Yusong-gu, Daejeon 305-333, Republic of Korea
}

Correspondence

Wan-Taek Im wandra@kaist.ac.kr

Jung-Sook Lee

jslee@kribb.re.kr
The genus Vagococcus was proposed by Collins et al. (1989) and described as a phylogenetically distinct group of Grampositive cocci that resemble lactococci. The first species to be identified was Vagococcus fluvialis (Collins et al., 1989), which was isolated from chicken faeces (Hashimoto et al., 1974). Later, Vagococcus salmoninarum was isolated from diseased fish (Wallbanks et al., 1990), Vagococcus lutrae was recovered from the common otter (Lawson et al., 1999) and Vagococcus fessus (Hoyles et al., 2000), Vagococcus carniphilus (Shewmaker et al., 2004), Vagococcus elongatus (Lawson et al., 2007) and Vagococcus penaei (Jaffrès et al., 2010) were isolated from seal and harbour porpoise, ground beef, a swine-manure storage pit and spoiled cooked shrimp, respectively.

In this study, a Vagococcus-like strain, $\mathrm{AC}-1^{\mathrm{T}}$, was isolated from an acidogenic fermentation bioreactor in a food wastewater treatment plant in Naju province, South Korea. A suspension sample was serially diluted with $50 \mathrm{mM}$ phosphate buffer ( $\mathrm{pH} 7.0)$ and incubated on trypticase soy agar (TSA; Difco) at $30{ }^{\circ} \mathrm{C}$ for 1 week. Single colonies on the plates were purified by subcultivation on nutrient agar

The GenBank/EMBL/DDBJ accession number for the 16S rRNA gene sequence of strain $A C-1^{\top}$ is FJ211190.

A supplementary table is available with the online version of this paper.
(NA) or TSA. Strain AC-1 ${ }^{\mathrm{T}}$ was routinely cultured on TSA at $30{ }^{\circ} \mathrm{C}$ and maintained as a glycerol suspension $(20 \%$, $\mathrm{w} / \mathrm{v})$ at $-70{ }^{\circ} \mathrm{C}$.

Gram-reaction testing was performed by the non-staining method as described by Buck (1982). Cell morphology was observed at $\times 1000$ magnification with a light microscope (Nikon) using cells grown for $24 \mathrm{~h}$ at $30{ }^{\circ} \mathrm{C}$ on TSA. Catalase activity was determined by bubble production in $3 \%(\mathrm{v} / \mathrm{v}) \mathrm{H}_{2} \mathrm{O}_{2}$ and oxidase activity was determined using $1 \%(\mathrm{w} / \mathrm{v})$ tetramethyl $p$-phenylenediamine. Carbon-source utilization and some enzyme activities were tested at $30{ }^{\circ} \mathrm{C}$ with the API $20 \mathrm{NE}$, API ZYM and API $50 \mathrm{CH}$ systems (bioMérieux), according to the instructions of the manufacturer. Anaerobic growth was tested in serum bottles containing trypticase soy broth (TSB; Difco) and $1 \mathrm{~g}$ thioglycolate $\mathrm{l}^{-1}$ with nitrogen gas as the headspace. Tests for the degradation of DNA (DNase agar; Scharlau; tested by flooding plates with $1 \mathrm{M} \mathrm{HCl}$ ), casein, chitin, starch (Atlas 1993), lipid (Kouker \& Jaeger, 1987), xylan and cellulose (Ten et al., 2004) were evaluated after 10 days. The test for haemolysis was performed using TSA supplemented with $5 \%$ defibrinated sheep blood. Growth at $4,15,25,30,37,42$ and $45{ }^{\circ} \mathrm{C}$, at different $\mathrm{pH}$ and with $1-10 \%(\mathrm{w} / \mathrm{v}) \mathrm{NaCl}$ was assessed in TSB after 5 days. Growth was estimated by monitoring 
$\mathrm{OD}_{600}$. Growth on NA and MacConkey agar was also evaluated at $30{ }^{\circ} \mathrm{C}$.

Extraction of the genomic DNA of strain $\mathrm{AC}-\mathrm{1}^{\mathrm{T}}$ was achieved using a commercial genomic DNA-extraction kit (Solgent). The 16S rRNA gene was amplified from chromosomal DNA using the universal bacterial primer set $9 \mathrm{~F}$ and $1512 \mathrm{R}$ and purified PCR products were sequenced by Solgent (Ten et al., 2008). The full sequence of the 16S rRNA gene was compiled using SeqMan (DNASTAR). 16S rRNA gene sequences of related taxa were obtained from the GenBank database. Multiple alignments were performed using CLUSTAL X (Thompson et al., 1997). Gaps were edited in the BioEdit program (Hall, 1999). Evolutionary distances were calculated using Kimura's two-parameter model (Kimura, 1983). Phylogenetic trees were reconstructed using the neighbour-joining (Saitou \& Nei, 1987) and maximum-parsimony (Fitch, 1971) methods in MEGA4 (Kumar et al., 2008) and bootstrap calculations were based on 1000 replications (Felsenstein, 1985). Sequence similarities were calculated using the EzTaxon server (http://www.eztaxon.org/; Chun et al., 2007).

For measurement of the $\mathrm{G}+\mathrm{C}$ content of chromosomal DNA, genomic DNA of strain AC- $1^{\mathrm{T}}$ was extracted and purified as described by Moore \& Dowhan (1995) and degraded enzymically into nucleosides. The $\mathrm{G}+\mathrm{C}$ content was determined as described by Mesbah et al. (1989) using reversed-phase HPLC. Cellular fatty acid profiles were determined for cells grown on TSA for 3 days at $30{ }^{\circ} \mathrm{C}$. Cellular fatty acids were saponified, methylated and extracted according to the protocol of the Sherlock Microbial Identification System (MIDI). Fatty acids were analysed by GC (6890; Hewlett Packard) and identified using the Microbial Identification software package (Sasser, 1990).

Cells of strain AC-1 ${ }^{\mathrm{T}}$ were Gram-staining-positive, facultatively anaerobic, non-spore-forming, non-motile cocci that were elongated in the direction of the chain. Colonies grown on TSA for 3 days were smooth, circular, white and convex, $0.2 \mathrm{~mm}$ in diameter. The novel strain barely grew on MRS agar and NA. On TSA, strain AC- $1^{\mathrm{T}}$ was able to grow at $15-37{ }^{\circ} \mathrm{C}$, but not at 4 or $42{ }^{\circ} \mathrm{C}$. The physiological characteristics of strain $\mathrm{AC}-1^{\mathrm{T}}$ are summarized in the species description and Table 1 lists the characteristics that serve to differentiate strain $\mathrm{AC}-1^{\mathrm{T}}$ from its closest phylogenetic relatives.

An almost-complete 16S rRNA gene sequence (1450 bp) of strain $\mathrm{AC}-1^{\mathrm{T}}$ (positions 59-1499 with respect to the Escherichia coli numbering system) was determined. The closest relatives of strain $\mathrm{AC}-1^{\mathrm{T}}$ were $V$. elongatus $\mathrm{PPC}^{\mathrm{T}}$ (97.4\% 16S rRNA gene sequence similarity), $V$. penaei $\mathrm{CD}^{276^{\mathrm{T}}} \quad(96.7 \%), \quad$ V. carniphilus ATCC BAA- $640^{\mathrm{T}}$ $(96.6 \%)$, V. fluvialis CCUG $32704^{\mathrm{T}}(96.6 \%)$, V. lutrae CCUG $39187^{\mathrm{T}}(96.2 \%)$ and $V$. salmoninarum CCUG $33394^{\mathrm{T}}(94.8 \%)$. Lower sequence similarities $(<94.7 \%)$ were found with all other type strains of recognized species of the family Enterococcaceae. This relationship between
Table 1. Differential phenotypic characteristics of strain AC-1 ${ }^{\top}$ and type strains of species of the genus Vagococcus

Strains: 1 , Vagococcus acidifermentans sp. nov. AC $-1^{\mathrm{T}} ; 2, V$. elongatus DSM $21480^{\mathrm{T}} ; 3$, V. carniphilus ATCC BAA $-640^{\mathrm{T}} ; 4$, V. fluvialis CCUG $32704^{\mathrm{T}}$; 5, V. lutrae CCUG $39187^{\mathrm{T}} ; 6$, V. salmoninarum CCUG $33394^{\mathrm{T}}$; 7, V. fessus DSM $15697^{\mathrm{T}}$. All data were obtained in this study. All strains are positive for acid phosphatase and acid production from D-fructose. All strains are negative for lipase (C14), trypsin, $\beta$ galactosidase, $\alpha$-fucosidase, $\alpha$-mannosidase, $\beta$-glucuronidase and acid production from erythritol, L-xylose, L-sorbose, L-rhamnose, methyl $\alpha$-D-mannopyranoside, melibiose, inulin, melezitose, raffinose, starch, glycogen, D-lyxose, 2-ketogluconate, 5-ketogluconate and D-fucose. + , Positive; $\mathrm{w}$, weakly positive; - , negative.

\begin{tabular}{|c|c|c|c|c|c|c|c|}
\hline Characteristic & 1 & 2 & 3 & 4 & 5 & 6 & 7 \\
\hline \multicolumn{8}{|c|}{ Acid production from (API $50 \mathrm{CH}$ ): } \\
\hline Glycerol & + & + & + & - & + & - & - \\
\hline D-Arabinose & - & - & + & - & - & - & - \\
\hline L-Arabinose & - & + & - & + & - & - & + \\
\hline D-Ribose & + & - & + & + & + & - & - \\
\hline D-Xylose & + & - & - & - & - & - & - \\
\hline Adonitol & + & - & - & - & - & - & - \\
\hline Methyl $\beta$-D-xylose & + & - & - & - & - & - & - \\
\hline D-Galactose & + & - & - & - & - & - & $\mathrm{w}$ \\
\hline D-Glucose & + & - & + & - & + & + & + \\
\hline D-Mannose & - & - & - & + & - & - & - \\
\hline Dulcitol & + & - & - & - & - & - & - \\
\hline Inositol & $\mathrm{w}$ & + & - & + & - & - & - \\
\hline D-Mannitol & + & + & - & - & + & - & - \\
\hline D-Sorbitol & - & - & - & + & + & - & - \\
\hline Methyl $\alpha$-D-glucopyranoside & + & - & + & - & + & - & - \\
\hline$N$-Acetylglucosamine & + & - & + & - & + & - & - \\
\hline Amygdalin & + & - & - & - & + & - & - \\
\hline Arbutin & + & - & - & - & + & + & - \\
\hline Aesculin & + & - & + & - & + & + & - \\
\hline Salicin & - & - & + & - & + & + & - \\
\hline Cellobiose & + & + & - & - & + & + & - \\
\hline Maltose & + & - & + & - & + & - & - \\
\hline Lactose & + & - & - & - & - & - & - \\
\hline Sucrose & + & - & - & + & w & + & - \\
\hline Trehalose & + & - & + & + & w & + & w \\
\hline Xylitol & $\mathrm{w}$ & - & - & - & + & - & - \\
\hline Gentiobiose & + & - & - & - & + & + & - \\
\hline Turanose & + & - & - & - & + & - & w \\
\hline D-Tagatose & + & - & - & - & $\mathrm{w}$ & + & + \\
\hline L-Fucose & - & - & + & - & - & - & - \\
\hline D- and L-Arabitol & + & - & - & - & - & - & - \\
\hline Gluconate & + & - & - & - & - & - & - \\
\hline \multicolumn{8}{|l|}{ Enzymes (API ZYM) } \\
\hline Alkaline phosphatase & + & $\mathrm{w}$ & + & $\mathrm{w}$ & $\mathrm{w}$ & + & - \\
\hline Esterase lipase (C4) & + & $\mathrm{w}$ & + & + & + & + & $\mathrm{w}$ \\
\hline Esterase lipase (C8) & + & $\mathrm{w}$ & + & + & + & + & + \\
\hline Leucine arylamidase & + & - & + & + & + & + & + \\
\hline Valine arylamidase & - & - & - & + & - & $\mathrm{w}$ & - \\
\hline Cystine arylamidase & + & - & + & - & - & $\mathrm{w}$ & - \\
\hline$\alpha$-Chymotrypsin & + & $\mathrm{w}$ & - & + & + & + & + \\
\hline $\begin{array}{l}\text { Naphthol-AS-BI- } \\
\text { phosphohydrolase }\end{array}$ & + & $\mathrm{w}$ & + & + & + & - & + \\
\hline
\end{tabular}


Table 1. cont.

\begin{tabular}{|llllllll|}
\hline Characteristic & $\mathbf{1}$ & $\mathbf{2}$ & $\mathbf{3}$ & $\mathbf{4}$ & $\mathbf{5}$ & $\mathbf{6}$ & $\mathbf{7}$ \\
\hline$\alpha$-Galactosidase & - & + & - & - & + & - & - \\
$\alpha$-Glucosidase & + & - & + & - & + & - & - \\
$\beta$-Glucosidase & - & - & - & $\mathrm{W}$ & + & + & - \\
$N$-Acetyl- $\beta$-glucosaminidase & - & - & - & - & + & - & - \\
& & & & & & & \\
\hline
\end{tabular}

strain $\mathrm{AC}-1^{\mathrm{T}}$ and other members of the genus Vagococcus was also evident in the phylogenetic analysis based on 1400 nt. Strain AC- $1^{\mathrm{T}}$ and the seven members of the genus Vagococcus formed a monophyletic lineage supported by a bootstrap value of $100 \%$ that was recovered by both of the tree-making methods employed in this study (Fig. 1).

DNA-DNA hybridization was performed between strain $\mathrm{AC}-1^{\mathrm{T}}$ and $V$. elongatus DSM $21480^{\mathrm{T}}$ with the method described by Ezaki et al. (1989) using photobiotin-labelled DNA probes and microdilution wells. Hybridization was performed with five replications for each sample. The highest and lowest values obtained for each sample were excluded and the means of the remaining three values were converted to percentage values. DNA-DNA relatedness between strain $\mathrm{AC}-1^{\mathrm{T}}$ and $V$. elongatus $\mathrm{DSM} 21480^{\mathrm{T}}$ was $11 \%$, which was low enough to assign strain $\mathrm{AC}-1^{\mathrm{T}}$ to a novel species of genus Vagococcus (Wayne et al., 1987).

The $\mathrm{G}+\mathrm{C}$ content of genomic DNA of strain $\mathrm{AC}-1^{\mathrm{T}}$ was $44.2 \mathrm{~mol} \%$. The fatty acid profiles of strain $\mathrm{AC}-1^{\mathrm{T}}$ and the seven members of the genus Vagococcus are shown in Supplementary Table S1 (available in IJSEM Online). The fatty acid profile of strain $\mathrm{AC}-1^{\mathrm{T}}$ was composed mainly of $\mathrm{C}_{18: 1} \omega 9 c(24.8 \%), \mathrm{C}_{16: 0}(19.5 \%)$, summed feature 4 $\left(\mathrm{C}_{16: 1} \omega 7 c\right.$ and/or iso- $\left.\mathrm{C}_{15: 0} 2-\mathrm{OH} ; 7.7 \%\right), \mathrm{C}_{18: 0}(7.4 \%)$, $\mathrm{C}_{16: 1} \omega 9 c(6.8 \%)$ and $\mathrm{C}_{14: 0}(6.4 \%)$, which is typical of members of the genus Vagococcus. However, some minor qualitative and quantitative differences in fatty acid content

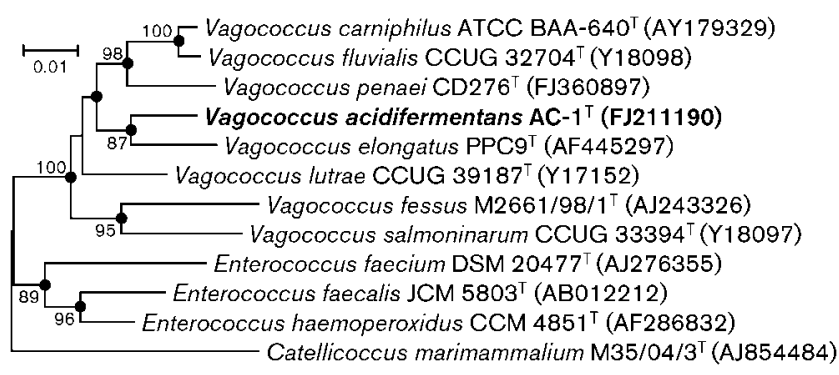

Fig. 1. Neighbour-joining phylogenetic tree based on 16S rRNA gene sequences showing the relationships between strain $A C-1{ }^{\top}$ and related type strains. Filled circles indicate that the corresponding nodes were also recovered in a tree generated with the maximum-parsimony algorithm. Bootstrap values $(>70 \%)$ based on 1000 replications are shown at branch nodes. Bar, 0.01 substitutions per nucleotide position. could be observed between strain $\mathrm{AC}-1^{\mathrm{T}}$ and its closest phylogenetic relatives.

The results obtained from phenotypic and phylogenetic characterization indicated that strain $\mathrm{AC}-1^{\mathrm{T}}$ belongs to the genus Vagococcus. Phylogenetic distinctiveness and DNADNA relatedness, in addition to some phenotypic differences (Table 1), confirmed that strain $\mathrm{AC}-1^{\mathrm{T}}$ represented a species that is distinct from recognized Vagococcus species. Therefore, on the basis of the data presented, strain AC- $1^{\mathrm{T}}$ should be classified in a novel species of the genus Vagococcus, for which the name Vagococcus acidifermentans sp. nov. is proposed.

\section{Description of Vagococcus acidifermentans sp. nov.}

Vagococcus acidifermentans (a.ci.di.fer.men'tans. N.L. neut. n. acidum acid; N.L. part. adj. fermentans fermenting; N.L. part. adj. acidifermentans fermenting to an acid).

Cells are Gram-staining-positive, facultatively anaerobic, non-spore-forming, non-motile cocci after 3 days on TSA. Colonies after 3 days on TSA are smooth, white and convex, $0.2 \mathrm{~mm}$ in diameter. Grows well at $15-37{ }^{\circ} \mathrm{C}$ (but not at 4 or $42{ }^{\circ} \mathrm{C}$ ) and at $\mathrm{pH} 4.0-9.0$. Growth occurs with $0-1.0 \%(\mathrm{w} / \mathrm{v}) \mathrm{NaCl}$, but not with $2.0 \%$ (w/v) $\mathrm{NaCl}$. Grows weakly on MRS agar and NA. Catalase- and oxidasenegative. Does not reduce nitrate to nitrite. Indole and $\mathrm{H}_{2} \mathrm{~S}$ is not produced. Negative for haemolysis and production of arginine dihydrolase, urease and protease (gelatin hydrolysis). Acid production from sole carbon sources (API $50 \mathrm{CH}$ ) and enzyme activities (API ZYM) are listed in Table 1. $\mathrm{C}_{18: 1} \omega 9 c, \mathrm{C}_{16: 0}$, summed feature $4\left(\mathrm{C}_{16: 1} \omega 7 c\right.$ and/ or iso- $\left.\mathrm{C}_{15: 0} 2-\mathrm{OH}\right), \mathrm{C}_{18: 0,}, \mathrm{C}_{16: 1} \omega 9 c$ and $\mathrm{C}_{14: 0}$ are the major cellular fatty acids $(>6 \%)$. The DNA G $+\mathrm{C}$ content of the type strain is $44.2 \mathrm{~mol} \%$ (HPLC).

The type strain, $\mathrm{AC}-1^{\mathrm{T}}\left(=\right.$ KCTC $\left.13418^{\mathrm{T}}=\mathrm{LMG} 24798^{\mathrm{T}}\right)$, was isolated from an acidogenic fermentation bioreactor in a food wastewater treatment plant in Naju province, South Korea.

\section{Acknowledgements}

This work was supported by the 21C Frontier Microbial Genomics and Applications Center Program, Ministry of Education, Science \& Technology (grant no. MG08-0101-2-0), the office of the KAIST EEWS Initiative (EEWS: Energy, Environment, Water, and Sustainability) and a grant from the KRIBB Research Initiative Program of Republic of Korea.

\section{References}

Atlas, R. M. (1993). Handbook of Microbiological Media. Edited by L. C. Parks. Boca Raton, FL: CRC Press.

Buck, J. D. (1982). Nonstaining ( $\mathrm{KOH})$ method for determination of gram reactions of marine bacteria. Appl Environ Microbiol 44, 992-993.

Chun, J., Lee, J.-H., Jung, Y., Kim, M., Kim, S., Kim, B. K. \& Lim, Y.-W. (2007). EzTaxon: a web-based tool for the identification of 
prokaryotes based on 16S ribosomal RNA gene sequences. Int J Syst Evol Microbiol 57, 2259-2261.

Collins, M. D., Ash, C., Farrow, J. A., Wallbanks, S. \& Williams, A. M. (1989). $16 \mathrm{~S}$ ribosomal ribonucleic acid sequence analyses of lactococci and related taxa. Description of Vagococcus fluvialis gen. nov., sp. nov. J Appl Bacteriol 67, 453-460.

Ezaki, T., Hashimoto, Y. \& Yabuuchi, E. (1989). Fluorometric deoxyribonucleic acid-deoxyribonucleic acid hybridization in microdilution wells as an alternative to membrane filter hybridization in which radioisotopes are used to determine genetic relatedness among bacterial strains. Int J Syst Bacteriol 39, 224-229.

Felsenstein, J. (1985). Confidence limit on phylogenies: an approach using the bootstrap. Evolution 39, 783-791.

Fitch, W. M. (1971). Toward defining the course of evolution: minimum change for a specific tree topology. Syst Zool 20, 406-416.

Hall, T. A. (1999). BioEdit: a user-friendly biological sequence alignment editor and analysis program for Windows 95/98/NT. Nucleic Acids Symp Ser 41, 95-98.

Hashimoto, H., Noborisaka, R. \& Yanagawa, R. (1974). [Distribution of motile streptococci in man, animals and natural environment]. Nippon Saikingaku Zasshi 29, 387-393 (in Japanese).

Hoyles, L., Lawson, P. A., Foster, G., Falsen, E., Ohlén, M., Grainger, J. M. \& Collins, M. D. (2000). Vagococcus fessus sp. nov., isolated from a seal and a harbour porpoise. Int J Syst Evol Microbiol 50, 11511154.

Jaffrès, E., Prévost, H., Rossero, A., Joffraud, J. J. \& Dousset, X. (2010). Vagococcus penaei sp. nov., isolated from spoilage microbiota of cooked shrimp (Penaeus vannamei). Int J Syst Evol Microbiol 60, 2159-2164.

Kimura, M. (1983). The Neutral Theory of Molecular Evolution. Cambridge: Cambridge University Press.

Kouker, G. \& Jaeger, K.-E. (1987). Specific and sensitive plate assay for bacterial lipases. Appl Environ Microbiol 53, 211-213.

Kumar, S., Nei, M., Dudley, J. \& Tamura, K. (2008). MEGA: a biologistcentric software for evolutionary analysis of DNA and protein sequences. Brief Bioinform 9, 299-306.

Lawson, P. A., Foster, G., Falsen, E., Ohlén, M. \& Collins, M. D. (1999). Vagococcus lutrae sp. nov., isolated from the common otter (Lutra lutra). Int J Syst Bacteriol 49, 1251-1254.
Lawson, P. A., Falsen, E., Cotta, M. A. \& Whitehead, T. R. (2007). Vagococcus elongatus sp. nov., isolated from a swine-manure storage pit. Int J Syst Evol Microbiol 57, 751-754.

Mesbah, M., Premachandran, U. \& Whitman, W. B. (1989). Precise measurement of the $\mathrm{G}+\mathrm{C}$ content of deoxyribonucleic acid by highperformance liquid chromatography. Int J Syst Bacteriol 39, 159-167.

Moore, D. D. \& Dowhan, D. (1995). Preparation and analysis of DNA. In Current Protocols in Molecular Biology, pp. 2-11. Edited by F. M. Ausubel, R. Brent, R. E. Kingston, D. D. Moore, J. G. Seidman, J. A. Smith \& K. Struhl. New York: Wiley.

Saitou, N. \& Nei, M. (1987). The neighbor-joining method: a new method for reconstructing phylogenetic trees. Mol Biol Evol 4, 406-425.

Sasser, M. (1990). Identification of bacteria by gas chromatography of cellular fatty acids, MIDI Technical Note 101. Newark, DE: MIDI Inc.

Shewmaker, P. L., Steigerwalt, A. G., Morey, R. E., Carvalho, M. G., Elliott, J. A., Joyce, K., Barrett, T. J., Teixeira, L. M. \& Facklam, R. R. (2004). Vagococcus carniphilus sp. nov., isolated from ground beef. Int J Syst Evol Microbiol 54, 1505-1510.

Ten, L. N., Im, W.-T., Kim, M.-K., Kang, M.-S. \& Lee, S.-T. (2004). Development of a plate technique for screening of polysaccharidedegrading microorganisms by using a mixture of insoluble chromogenic substrates. J Microbiol Methods 56, 375-382.

Ten, L. N., Jung, H.-M., Im, W. T., Yoo, S. A. \& Lee, S.-T. (2008). Lysobacter daecheongensis sp. nov., isolated from sediment of stream near the Daechung dam in South Korea. J Microbiol 46, 519-524.

Thompson, J. D., Gibson, T. J., Plewniak, F., Jeanmougin, F. \& Higgins, D. G. (1997). The CLUSTAL_X windows interface: flexible strategies for multiple sequence alignment aided by quality analysis tools. Nucleic Acids Res 25, 4876-4882.

Wallbanks, S., Martinez-Murcia, A. J., Fryer, J. L., Phillips, B. A. \& Collins, M. D. (1990). $16 \mathrm{~S}$ rRNA sequence determination for members of the genus Carnobacterium and related lactic acid bacteria and description of Vagococcus salmoninarum sp. nov. Int J Syst Bacteriol 40, 224-230.

Wayne, L. G., Brenner, D. J., Colwell, R. R., Grimont, P. A. D., Kandler, O., Krichevsky, M. I., Moore, L. H., Moore, W. E. C., Murray, R. G. E. \& other authors (1987). International Committee on Systematic Bacteriology. Report of the ad hoc committee on reconciliation of approaches to bacterial systematics. Int J Syst Bacteriol 37, 463-464. 